\title{
The Need of Adult Education and Training Administration in Lifelong Learning
}

\author{
Namık Kemal Demir ${ }^{1 *}$
}

${ }^{1}$ Retired Teacher from National Ministry of Education of Turkey, TURKEY

*Corresponding Author: nkdemir@hotmail.com

Citation: Demir, N. K. (2020). The Need of Adult Education and Training Administration in Lifelong Learning. Mediterranean Journal of Social \& Behavioral Research, 4(3), 41-45. https://doi.org/10.30935/mjosbr/9600

\begin{abstract}
Lifelong learning is the constant updating of a person's knowledge, skills and competencies throughout his life. Undoubtedly, life-longlearning and adulteducation are not only vocational-technical but also socially andculturally necessary, since life change and renewal are not one-dimensional. In the global world, where knowledge and skills are rapidly deteriorating and insufficient, everyone has the right and the need to renew and develop themselves by continuously benefiting from lifelong learning and adult education services. It is seen that the LLL cannot achieve its goals and the target scannot be achieved. According to the results of the International Evaluation of Adult Competencies Program; A large majority of adults lack the skills required by the era, levels of education in Turkey can not it be effective in skills training, skills biggest difference between men andwomen in Turkey. These results are valid between the ages of thirty-sixty-five. In addition to this, starting from MEB, the graduates of the LLL and continuing education centers, who are mainly engineers, operators or other fields, are chaired / headed. It is not uncommon for the graduates of the Education administration departments of the Education Faculties to take part in the administration of the secenters. The aim of our study is to reveal the contribution of the graduates of Education administration, who will work in LLL centers, to the system. Therefore, this research is a qualitative research usingthe "document analysis" method. For this purpose, the literature related to LLL and Educationadministration has been scannedand it is planned to reveal possible results by reaching the data.

Keywords: lifelong learning, adult education, education administration, education administrator

Received: 10 Aug. 2020 • Revised: 13 Sep. 2020 • Accepted: 10 Nov. 2020
\end{abstract}

\section{INTRODUCTION}

Today, where science and technology develop very quickly and knowledge can be controlled very hard, developments should be reflected especially to people who have completed their education. Today, every person over thirty years of age in Turkey must have been subjected to the reform, rhetoric, which promises to end problems such as learning, quality and access in education. Looking back, we see that many good ideas, initiatives, plans and programmes remained on dusty shelves in education. One of them is lifelong education, adult education. Lifelong learning is a person's constant update of their knowledge, skills and competencies throughout their life.

Undoubtedly, since change and regeneration in life are not onedimensional, lifelong learning and adult education are necessary not only from a professional-technical care, but also from a social and cultural care. In a global world where knowledge, skills are rapidly becoming old and inadequate, no matter what level of education they receive, everyone has both the right and the need to renew and improve themselves by constantly benefiting from lifelong learning and adult education services. When we look at the researches carried out in the field of lifelong learning in our country, it is seen that the lifelong learning has not achieved its objectives and the targets have not been achieved.

According to the results of the OECD's (2016) Programme for The International Assessment of Adult Competencies (PIAAC); The majority of adults lack the skills required by the age and the education levels in Turkey are not effective in gaining skills, and there is a big skills difference between men and women (Tedmem, 2016). In addition to all these, starting from meb, the graduates of the lifelong learning and continuous training centers, mainly engineers, operators or graduates of other fields are the president/director (Duman, 2006). It is not common for graduates of the department of education management of education faculties to take part in the management of these centers.

\section{METHOD}

The aim of our study is to reveal the contribution of the graduates of the department of education management who will work in the centers of the lifelong learning to the system. In the research, many euissued papers in the field of lifelong education and adult education were 
seen. Our work; Based on the results of the OECD 'International Assessment of Adult Competencies Program (PIAAC)' in our country, it is limited to thirty-sixty-five years of age. Research is a qualitative research using the "document analysis (review)" method. Document analysis is the analysis of written materials containing information about the facts and events to be investigated (Yildirim and Simsek, 2008). In addition, document analysis in qualitative research can be used as a stand-alone data collection method and includes analysis of written materials (Lightning and Lightning, 2008). In this respect, care has been taken to obtain data focused on research in line with the research problem. In this context, the field article on lifelong learning and education management was scanned and the data were reached and possible results were planned to be revealed.

\section{Lifelong Learning in the World}

The full ingest of the idea of lifelong education was expressed in the early XX century. In the 1920s, John Dewey and Eduard Lindeman and Basil Yeaxle established the political basis for a comprehensive understanding that looked at education as a continuous dimension of everyday life. Thus, an understanding that education is lifelong has come from the first time of system studies in the field of adult education (Ayhan, 2005). Since the beginning of the 1990s, the lifelong learning has started to be at the top of the agenda again all over the world (Duman. 2005; Hake, 2005).

The EU and many countries have prepared se-siyasa documents on the lifelong learning in a row, and are being sought to reach the learning community. For example, if you want to use The $1994 \mathrm{EU}$ white book on "Development, Competition and Functioning" emphasized that all nations should put the IU as a general goal. In 1995, the EU published the white book titled "Teaching and Learning: Towards the Learning Society", and 1996 was considered the year of "European Lifelong learning". Similarly, Japan passed the "Promotion of Lifelong learning Act" in 1990 and founded a "National Council on Lifelong learning." Scotland titled "Lifelong learning: The Way To Go" in 1997, the UK Department of Education and Employment, "Learning through Life" in 1995 and "Learning Age: Rebirth for a New England" in 1998; The Finnish Ministry of Education in 1997 "Learning Happiness"; The Irish Ministry of Education and Science published lifelong learning documents titled "Learning for Life" (Duman, 2005).

In 2000, the European Commission published a memorandum on lifelong learning of an important siyasa document. In this document, lifelong learning is defined as follows: All learning activities last a lifetime, built around six basic messages for the development of lifelong learning politics throughout Europe in order to improve knowledge, skills and adesies.

These six messages include: basic skills for all, more investment in human resources, bringing learning home, assessment of learning, rethinking guidance and consultation, innovations in teaching and learning. The memorandum was heavily debated between member and candidate countries in the first half of 2001. Responses to the memorandum were evaluated and reviewed by the Council of Europe and published at the end of 2001 as "Being European in the Field of Lifelong learning Reality”. This result was found in June 2002 by heads of state and government to learn lifelong. The Council of Europe adopted the Political Document reviewed by the European Commission and adopted it as a guide principle for education and education reform in member and candidate countries (Hake, 2005).

\section{Lifelong Learning in Turkey}

With lifelong learning in the world beginning to develop and gain importance, education has emerged as a key component of all educational activities covering both school education and out-of-school education, regardless of time and space. In the lifelong learning memorandum announced bythe European Union Commission in 2000 in our country, the following six basic strategies are necessary in the identification and dissemination of lifelong learning and the general framework of lifelong learning in the 21st century is determined:

- New basic skills for everyone,

- More investment in human resources,

- Development of innovations and new methods in education,

- Valuing/documenting all kinds of education,

- Review of guidance and consultancy services

- It is determined as using information communication technology to reach those who have difficulty accessing education as much as possible, lifelong learning approach for local and regional-based initiatives, multipurpose learning centers, and using information networks for the learning community.

In addition, today, where lifelong learning has become a valid option especially in acquiring knowledge/skills for employment and updating existing information, widespread education has gained importance and widespread educational opportunities have been developed in our country that appeal to all segments of the population. In this context, it is aimed to provide one-point access to the databases of the largest lifelong learning institutions in the country with lifelong learning. The general directorate of lifelong learning under the ministry of national education was established and training and job opportunities were initiated as well as the course programs offered by the public education centers affiliated to this general directorate. In this context, turkey lifelong learning strategy document and action plan (2014-2018) was adopted by the high planning board. http://hbogm.meb.gov.tr/

Lifelong learning strategy document for the period 2014-2018

The lifelong learning system, which started to be created with the lifelong learning strategy document of the period 2009-2013, is aimed to be more systematic in line with national and international approaches with the lifelong learning strategy document and action plan for the period 2014-2018. In the national lifelong learning strategy document for the period $2014-2018$, which is prepared to improve the effectiveness and efficiency of the lifelong learningsystem;

- Establishing a lifelong learning culture and awareness in society,

- Increasing lifelong learning opportunities and presentation,

- Increasing access to lifelong learning opportunities,

- Development of lifelong guidance and counseling system,

- Development of the system of recognition of previous learnings,

- The development of a lifelong learning monitoring and evaluation system has been prioritized (www.hbo.gov.tr). 


\section{Problems of Lifelong Learning in Turkey}

When we look at the studies carried out, it is revealed that the realization figures of the studies on lifelong learning in practice are very small.

Lifelong learning participation rate is based on the participation rate of individuals between the ages of 25 and 64 in the last 4 weeks in measuring the effectiveness and results of lifelong learning systems. This rate is determined by the household workforce survey conducted by TURKSTAT. Looking at the change in the participation rates of EU countries in lifelong learning between 2006 and 2012, the participation rate of lifelong learning in Turkey increased from 1.8 percent in 2006 to 3.2 percent in 2012 . The EU ( 27 countries) also fell from 9.5 per cent in 2006 to 9 per cent in 2012. This shows that the EU 2010 target remains below 12.5 percent and the 2020 target of 15 percent (THBÖSB and EP. 2014-2018). Looking at the participation rates of some countries in adult education in Europe, it is seen that it is $37.4 \%$ in Denmark, 30\% in Sweden and 20.1\% in the UK (Vezne, 2017).

Although Progress has been made in Turkey's lifelong learning participation rates (2007-2019) over the past thirteen years, it is seen that a planned effort must be made to achieve EU targets with the current level of 5.8 percent participation (YBGM, Monitoring and Evaluation Report 2019). There are criticisms about lifelong education applied in our country. For example: According to Bagci (2011), there are too large differences between Turkey and the European Union in terms of the situation in the areas of education problems and possible solutions. However, it can be observed that the reference framework in the basic policy texts that can be addressed under the title of lifelong education policies in Turkey is purely european union texts. This situation causes lifelong education to move away from the solution potentials of Turkey's educational problems as a concept that underlines that learning activity is widespread, continuously happening in all areas of life and in all areas of life that cannot be compressed into schools. Turkey needs a lifelong education approach that does not ignore universal values but seeks solutions by identifying its own educational needs on a more realistic ground.

Okçabol (2007) and Sayılan (2009), which specifically questioned the processes and dynamics of globalization affecting national education policies; (Kaya, 2014) emphasizes that the new economic understanding under the influence of globalization sees all public services as a commercial commodity and emphasizes the concept of "customer" instead of "citizen", while this transformation increases the need for social adult education approaches and negatively affects existing adult education services. Therefore, adult education, which feeds on people's lives, needs to produce solutions to people's life problems, but evaluating adult education studies with material elements causes other learning opportunities that people need to be ignored. At this point, vocational education in particular has started to be considered in a narrow environment as an adult learning away from the context of adult education. The data obtained as a result of the research conducted by Taşçı and others (2015) in Eskisehir primarily include lack of resources, human resources problems, lack of cooperation between stakeholders, lack of support offered to trainees after training and problems in the functioning of courses under the negative opinions indicated by managers and tutorials regarding lifelong learning environments.

Considering the meaning of the service it offers in Eskisehir and in general throughout Turkey and the size of the target audience reached, it is seen that more resources should be deseed to lifelong educational institutions such as public education centers. Another problem specifically identified by the managers is inadequate cooperation with the relevant institutions. In this context, the necessity of further relations with ISKUR and universities was emphasized by the participants. According to Hayatgönüșen (2019), the participation rate of lifelong learning activities is lower than in developed countries despite the increase and recordability in recent years. Alhowever, alhowever, the units affiliated with metropolitan municipalities have changed to some extent, the administrative-technical capacity and recognition in society of the units established for the purpose of continuous education or lifelong learning in different institutions is still not enough.

The level of awareness, interest and contribution of nongovernmental organizations in this area is lower than expected. The quality and standardization problem of the same type of lifelong learning programs offered by different institutions, including universities, continues to increase. There is no settled accreditation system and impact analysis studies of the trainings. For this reason, it is not possible to count pre-acquired skills in common education at certain rates in formal education. According to the results of the OECD's (2016) programme for the international assessment of adult competencies (PIAAC); In Turkey, the majority of adults lack the skills required by the age, and the education levels are not effective in gaining skills and there is the greatest skill difference between men and women. In addition, adults are without skills after compulsory training and cannot use their skills in their workplaces and in their daily lives.

These results apply to thirty-sixty-five-year-olds (Tedmem, 2016). In addition to all these, the graduates of the lifelong learning and continuous training centers affiliated to the MEB are mainly engineers, operators or graduates of other fields. Public education centers in districts are mostly run by non-expert managers, far from the needs of the public (Duman, 2006). It is not common for graduates of the department of education management of education faculties to take part in the management of these centers.

\section{Education Management and Lifelong Learning}

Education management is an "interdisciplinary" science created together by the disciplines of "education" and "management". Education management is the application of management science to education. EY is about implementing policies, decisions and objectives in the field of education. Ey, its main aim is to keep the Turkish national education system alive for educational policies as a whole and the objectives of the organization and to help create a positive climate organization in the learning teaching process (Yücesoy, Demir, Baglama, Bastas, Oznacar, 2020). For this purpose, education managers use the theories, methods and principles of general administration in order to co-ordination human and material resources, to make decisions and to direct group efforts (Balci and Aydin 2003). In order for the education manager to achieve all this, he needs to know the concepts and processes of education management well. In order for this concept to translate processes into behavior, it is mandatory for the education manager to have an academic education in this field. Individuals and groups inside and outside the institution where he works must also be well trained in behavioral science in order to take action towards the objectives of the institution (Bursalığlu, 2000).

With the rapid developments in technology, different areas of education have emerged as in many other fields. The increasing reality 
in education has led to the emergence of different areas of education as in many other areas in parallel with developments such as the use of social media (Bicen and Demir, 2020; Nacak, Baglama, Demir, 2020). One of them is lifelong learning. The education manager, who will take part in lifelong learning, has to manage his institution in a style suitable for his/her structure. Contemporary structuring requires the management of the institution with its own symbols and values. The voice and vision of the manager is an important coordination tool. Ensuring that education workers deleas themselves into training services and insevaluing them will necessite management with such symbols and values.

The education manager has to have a 'vision' for lifelong learning as a result of educational leadership. The vision is a low on what the BC will be in the near future, a great ideal. In order for this thought to be implemented, it is necessary to develop the mission of the lifelong learning in line with the vision. The mission is a task for the great thinking. These tasks, i.e. the mission, need to be institutionalized to find life. In this, it is necessary to connect concrete plans and projects of the mission. It is important to create a lifestyle, i.e. a culture, for the vision to be carried out in the lifelong learning. So everyone will see how what they're doing works, how it changes your life.

The lifelong learning should be organized as 'learning organizations' and managed with this understanding. Learning organizations are organizations that see research and learning as dynamo of change and development (Balci, 2000). When we look at the work of the general directorate of lifelong learning of meb; There is not a lot of employees who have graduated from education management in the general directorates and units, provincial and district national education directorates. Employees do not have the training manager's suffies. Because the text is translation, the vision is a mission passed in two sentences. Since the text of the lifelong learning was taken from the lifetime learning memorandum announced by the European Union Commission in 2000, it should first be re-edited according to the facts and need to learn about the lifelong learning.

\section{CONCLUSIONS AND RECOMMENDATIONS}

Today, the speed of change and increased knowledge in almost every field means that lifelong learning is now a necessity. No matter how qualified your education is in school, after entering the business world; If you do not follow the developments and renew yourself, the insement gap between life and you will always appear as negativity and failure. This is what adults in our country live in. The ministry of national education has a management and management problem that is not a graduate of education management. Unresolved management problems are naturally reflected in the lifelong learning. It is not often that educational faculties and educational scientists, especially adult educators, are involved in the management of these centers. The actual lifelong learning that occurs in the applications of managers with inadequate characteristics is the small number of people participating. As a result of miscommunication, the lifelong learning is not achieving its goal. The needs of the people, the realities of life are ignored.

Graduates of the department of education management should take part in the lifelong learning, starting from the headquarters of the general directorate. People who have taken training management courses should be included in the provincial and district public education centers. Education management graduates who will take part in the lifelong learning expect a difficult task. First of all, in cooperation with political institutions, universities and professional organizations, the lifelong learning should be provided to reach all adults of society. The text, which was created as a translation of the articles in the lifetime learning memorandum announced by the European Union Commission in 2000, should be re-edited according to the facts and need for learning that people in our country live in.

According to the results of the program for the international evaluation of adult competencies in our country; More importantly, adults do not gain skills after compulsory training. This results in people over thirty years of age in our country not adding anything new to their lives after compulsory education. An education reform should be initiated specifically for adults. In order to solve the lack of resources, human resources problems, lack of cooperation between stakeholders, lack of publicity, lack of support offered to trainees after training and problems in the functioning of courses in our country, studies should be initiated by the current general directorate of MEB, lifelong learning. In order to become a learning, ever-evolving society, the understanding that education is a lifelong process should be adopted everywhere.

\section{REFERENCES}

Ayhan, S. (2005). Dünden bugüne yaşam boyu öğrenme. In F. Sayılan, \& A. Yıldız (Eds.), Yaşam boyu öğrenme: sempozyum bildirileri ve tartşmalar: I. Yaşam boyu öğrenme sempozyumu, 9-10.

Bağcı, E. (2011). Avrupa Birliği’ne Üyelik Sürecinde Türkiye'de Yaşam Boyu Eğitim Politikaları. Ondokuz Mayis University Journal of Education, 30(2). https://doi.org/10.7822/egt41

Balcı, A. (2000). İkibinli yıllarda Türk milli eğitim sisteminin örgütlenmesi ve yönetimi. Kuram ve Uygulamada Egitim Yönetimi Dergisi, 6(4), 495-508.

Balcı, A., \& Pehlivan, İ. A. (2003). Eğitim Yönetimi. 2nd Edition. Ankara: Milli Eğitim Bakanlığı Yayınları.

Baş, B., \& Yıldız, F. İ. (2014). İlkokul Türkçe Ders Kitaplarının ResimMetin İlişkisi Açısından Öğretmen Görüşlerine Göre Değerlendirilmesi. Mustafa Kemal Üniversitesi Sosyal Bilimler Enstitüsü Dergisi, 11(28), 139-151.

Bicen, H., \& Demir, B. (2020). A Content Analysis on Articles Using Augmented Reality Technology and Infographic in Education. Postmodern Openings/Deschideri Postmoderne, 11. https://doi.org/10.18662/po/11.1sup1/121

Bursalığlu, Z. (2000). Okul yönetiminde yeni yapı ve davranıs. Ankara Üniversitesi Eğitim Fakültesi Yayınları.

Duman, A. (2005). Türkiye'de yaşam boyu öğrenme siyasalarını oluştur(a)mamanın dayanılmaz hafifliği. In F. Sayılan, \& A. Yıldız (Eds.), Yaşam boyu öğrenme: sempozyum bildirileri ve tartş̧malar: I. Yaşam boyu öğrenme sempozyumu, 9-10.

Erçetin, S. S., \& Arifoglu, A. (2016). Herkes İçin Eğitim 2015 Hedefleri ve Türkiye/Education for All 2015 Goals and Turkey. Bartin Üniversitesi Egitim Fakültesi Dergisi, 5(2), 223-246. https://doi.org/10.14686/buefad.v5i2.5000186142

Gürsoy, O. (2019). Akılh Kent Yaklaşım ve Türkiye’deki Büyükşshirler İçin Uygulama Imkanlan (Master's thesis, Sosyal Bilimler Enstitüsü). 
Hake, B. (2005). AB politikaları ve bilgi ekonomisi: Yaşam boyu öğrenme için stratejik bir rol Yaşam boyu öğrenme: Sempozyum bildirileri ve tartışmalar.

Kaya, H. E. (2014). Küresellesme Sürecinde Yasam Boyu Ögrenme ve Yetiskin Egitimi Gerçegi/Lifelong Learning and Adult Education Reality within the Scope of Globalization. Akademik Incelemeler Dergisi, 9(2), 91-111. https://doi.org/10.17550/aid.94961

MEB. İzleme ve değerlendirme raporu 2019. (2020). Yaşam Boyu Öğrenme Genel Müdürlüğü. İzleme ve Daire genel Başkanlığı: Ankara.

MEB. Türkiye Yaşam Boyu Öğrenme Strateji Belgesi ve Eylem Planı 2014-2018. (2014). Yaşam Boyu Öğrenme Genel Müdürlüğü. Yüksek Planlama Kurulu: Ankara.

Nacak, A., Bağlama, B., \& Demir, B. (2020). Teacher Candidate Views on the Use of YouTube for Educational Purposes. Online Journal of Communication and Media Technologies, 10(2), e202003. https://doi.org/10.29333/ojcmt/7827

Okçabol, R. (2007). Küreselleşme ve eğitim. Dipnot Yayınları: Ankara.
Sayılan, F. (2009). Küreselleşme ve yetişkin eğitimi. A. Yıldız, \& M. Uysal (Eds.).

Taşçı, D., et al. (2011). Eskişehir'de Yaşam Boyu Öğrenme Başlığı Altında Yetişkin Eğitiminin Analizi. Selçuk Ün. Sos. Bil. Ens. Der. (34).

TEDMEM. (2016). OECD Yetişkin Becerileri Araşttrmast: Türkiye ile Illgili Sonuçlar. Ankara: Türk Eğitim Derneği Yayınları.

Yıldız, A. T. D., \& Vezne, R. Y. (2017). Avrupa Birliğinin yaşam boyu öğrenme politikalan bağlamnda İngiltere, Danimarka ve Türkiyénin yetişkin eğitimi sistemlerinin karşslaştrmah analizi. Doctoral dissertation, Ankara Üniversitesi Eğitim Bilimleri Enstitüsü Yaşam Boyu Öğrenme ve Yetişkin Eğitimi Anabilim Dalı.

Yildirim, A., \& Simsek, H. (2008). Sosyal bilimlerde nitel arastirma yontemleri. Ankara: Seckin.

Yücesoy, Y., Demir, B., Bağlama, B., Baștaş, M., \& Öznacar, B. (2020). Secondary Education Teachers and School Administrators' Views on Positive Organizational Climate. Near East University Online Journal of Education,3(1), 12-21. https://doi.org/10.32955/ neuje.v3i1.188 